\title{
2 Theorising sexual violence in intimate relations in Scandinavia
}

\author{
A literature review
}

\author{
Margunn Bjørnholt
}

\section{Introduction}

Theories and concepts are crucial to all academic thinking, and the literature review is a mandatory element in academic writing. The theory is usually presented in the introduction and ideally is used as a tool for analysis. But it is also not unusual to use theories as stepping stones only by presenting them in superficial and often caricatured ways as a means of rendering them obsolete, irrelevant and in need of replacement. As Clare Hemmings (2005, 2011) has argued, such has been the fate of second-wave feminist work by successive generations of feminist scholars. Theories and concepts are rarely studied in their own right, despite their importance to academic thinking. Studying theories and theorisations is crucial to understanding particular phenomena and fields of study as well as for academic self-reflection.

This chapter contributes to such academic self-reflection within the Nordic context by providing an analytic review of how selected Scandinavian ${ }^{1}$ scholars use gender theories and gender perspectives in their theorisations of sexual violence. The chapter, which is a conceptual piece, describes different strands of thinking about gender in relation to sexual violence and explores the relationship between these strands, with a particular focus on their relevance for theorising sexual violence within intimate relations.

Studies of violence and sexual violence are characterised by increasing theoretical diversity and methodological sophistication (Hester \& Donovan, 2009; Brown \& Walklate, 2011; Walby et al., 2015; Walby \& Towers, 2017). Nevertheless, in contrast to the growing literature on the history of concepts and theory in the social sciences (Somers, 1995; Doucet, 2015), theories of violence and sexual violence have seldom been the object of study. In the Scandinavian context, Anne-Lie Steen's study (2003) of discursive struggles in the field of violence studies in Sweden is, to my knowledge, the only Nordic study to date to have focussed exclusively on theories in this field.

In this chapter, I analyse contemporary theorisations of rape and sexual violence found in a small sample of recent publications by Scandinavian scholars. Searches were made for works published between 2012 and 2017 in the following Norwegian, Swedish, Danish and general Nordic databases: Idunn, sociological abstracts 
from ProQuest (for Norway, Sweden and Denmark), Norart, Den danske forskningsbase and Swepub. The final selection of publications also relied on my general reading and prior knowledge of relevant authors and publications. The main criteria of selection included having a gender perspective and being involved with theories of gender and violence. Because of my choice of recent contributions only, the chapter presents a snapshot rather than tracing the genealogy and development of theories over time and generations. Five publications (by Norwegian, Danish and Swedish authors), representing four different theoretical approaches, were eventually selected for the present analysis. The four approaches include the continuum approach, a structural-intersectional approach, a dialectic approach and an institutional, complex-systems approach. The anthropologist Bo Wagner Sørensen's (2013) study, which uses the continuum approach, is the only contribution presented in this chapter to specifically address sexual violence as part of domestic violence.

In their article on young girls' experiences of unwanted sexual touching, Kari Stefansen, Ingrid Smette and Dagmara Bossy (2014) also draw on the continuum approach to link the experiences of unwanted touching by acquaintances, friends and strangers to a normative theory of gender freedom; their approach is also potentially relevant for studying sexual violence in intimate relations.

Ulrika Andersson, Monika Edgren, Lena Karlsson and Gabriella Nilsson (2016), in their research project on genres of rape narratives in Sweden, study how stories of rape are told in three different contexts: in the legal system, in the media and in autobiographic material within social media. Using a structural-intersectional approach that invokes the early feminist conceptualisations of victimisation and agency, the authors draw on narrative theory and theories of genres to examine how rape is discursively produced in these three contexts.

Lena Gunnarsson (2018) suggests a dialectic approach inspired by critical realism, with a focus on the relations between experiences and discourses. She develops her argument by exploring the tensions between hegemonic discourses on rape and the more ambiguous experiences found in autobiographic stories by victims of different genders. The approaches represented by Andersson et al. (2016) and Gunnarsson (2018) are related, in that both in different ways combine cultural perspectives and different strands of radical feminist perspectives. I have still chosen to treat them separately, however, as they take as starting points two different strands of radical feminist thought.

In their book Stopping Rape, Sylvia Walby and co-authors (2015) develop a new holistic approach in which they argue that using a broad, institutional, complex-systems approach is necessary in theorising about and preventing rape. This approach most clearly differs from the other approaches in its focus on the macro level.

The first part of this chapter presents the four approaches. The analysis focusses on the authors' use of core concepts such as victimhood and agency as well as how the authors apply gender perspectives and integrate gender theories in their analyses. The different theoretical approaches are analysed in the latter part of the chapter, with the aim of identifying common themes and differences 


\section{0}

Margunn Bjørnholt

and discussing how using various approaches might be useful in making sense of sexual violence within intimate relations as a gendered phenomenon.

\section{The continuum approach}

\section{Sexual violence as part of intimate partner violence}

In his article on sexual violence within the narratives of victims of domestic violence in the Danish context, Sørensen (2013) found that the victims of domestic violence in his study did not necessarily distinguish between sexual violence and violence in general. Rather, for some 'it was just part of the whole' (69). Sørensen discusses this finding in relation to the general perception among researchers and practitioners of rape as being a particularly vicious form of violence; he argues that the analytic distinction between different forms of violence that researchers and practitioners typically make does not necessarily correspond to victims' experiences of intimate partner violence (IPV) as a total 'package' (2013).

Sørensen (2013) argues that the continuum approach is suitable for studying violence as a lived experience. The continuum approach, originally formulated by Liz Kelly (1987, 1988a, 1988b), starts with the idea that violence is present in all women's lives, while differences exist in the forms the violence takes and how different women define particular incidents. The concept is not a matter of a degree of seriousness; rather, Kelly argues that establishing hierarchies of forms of violence is problematic (1987, p. 49). Kelly uses the term 'sexual violence' for all forms of violence because of the difficulty in distinguishing between physical violence and sexual violence $(1987$, p. 59, footnote 1).

In his theoretical framing of the article, Sørensen (2013) places the continuum approach in a feminist understanding of violence as being rooted in power relations between men and women in which violence is linked to gendered identities and cultural perceptions of gender and gendered privileges. Sørensen argues that while several researchers have used the continuum approach, they have mainly used it on a descriptive level and have not fully utilised the approach's analytical potential (2013). Kelly (1988b) proposes two possible uses of the continuum. The first use is on a more abstract level, as a continuum of different means of male power and control over women; different incidents and topics are linked, thereby recognising their interconnectedness. The second use is the continuum's application on an empirical level by establishing links between everyday sexist male behaviours and the less frequent forms of abuse defined as crimes.

In defining violence, Sørensen (2013) draws on David Riches's (1986) tripartite definition of interpersonal violence as always involving a victim, a perpetrator and one or more witnesses. In Sørensen's conceptualisation, witnesses can be understood as all actors who may have an effect on the interpretation of the violent act (2013). The general social climate towards violence and the recognition over the last fifty years of violence as a social problem - both a result of the international and national women's movements - have changed the relationship 
between victim and perpetrator and have reduced perpetrators' power of interpretation. Inspired also by Sally Engle Merry's work (2003, 2009), Sørensen (2013) suggests that victims of violence are legitimate victims, in the sense of legal subjects who have had their human rights violated. This understanding avoids the futile discussions of the problems with attributing or claiming a victim identity, which is associated with stigmatisation, passivity and lack of agency. In contrast, Sørensen (2013) argues, no antagonism exists between the position of a violated legal subject and agency, as illustrated in the concept of 'survivor' used by victims of rape and sexual abuse. Rather, recognition of the experience of being a victim is the prerequisite of being a survivor. Sørensen's (2013) main contribution is to reintegrate sexual violence into the understanding of IPV by theorising from victims' experiences and drawing on the concept of a continuum of violence that links other acts of IPV and sexual violence.

\section{Unwanted touching on a continuum of sexual violence}

In their article on young girls' experiences of unwanted sexual touching from acquaintances and strangers, Stefansen et al. (2014) also use the continuum approach; they see mild sexual violations as (1) being different from severe sexual violations, (2) connected at an experiential level and (3) linked to an underlying gender-power dimension. They view the approach as useful in elucidating differences within the same form of violation. The authors refer to the two different lexical definitions of a 'continuum' that Kelly (1988a, p. 76) refers to: what is common to different incidents versus a series of incidents that may be difficult to separate. Stefansen et al. (2014) use the latter definition as an opportunity to identify different forms of unwanted touching and to create a typology of such sexual violations.

Stefansen et al. (2014) also draw on Carol Smart's work (1995) on the 'disciplining' effects on all women of accumulated minor sexual offences and the importance of studying minor sexual offences as constitutive of gender-power relations, in that they confirm the lack of bodily protection and women's lack of the right to be left alone, in contrast to men. Both unwanted sexual touching and rape are 'demonstrations of the same problem of women being constituted as sexualized' bodies (Smart, 1995, p. 223, cited in Stefansen et al., 2014, p. 6). Stefansen et al. (2014) argue that minor assaults - such as in Smart's (1995) example of a woman who had her breast squeezed in public by a stranger - not only affect the particular woman but also serve as a reminder to all women of their vulnerability, hence contributing to a diffuse, latent fear (Sheffield, 1989) that then blurs the boundary between normal male aggression and more rare forms that 'shade into one another' (Kelly, 1988a, p. 75, cited in Stefansen et al., 2014, p. 6). Still drawing on Smart (1995), however, the authors argue that it is also important to recognise the potential ambiguity of such experiences, since the same incident may simultaneously make a woman feel attractive and incite fear within her.

Finally, Stefansen et al. (2014) draw on the Norwegian legal scholar Tove Stang Dahl's (1994) definition of sexual violence as a violation of gender 


\section{Margunn Bjørnholt}

freedom. Dahl (1994) argued that the strong focus on violence and the use of physical force in rape cases may overshadow other aspects of force preceding the rape act, such as confinement. Using rape in the context of hitchhiking as an example, Dahl argued that the crime in this particular case started when the driver took the victim to a different destination than agreed upon, did not let her out when she asked and locked the doors to prevent her from escaping. Stefansen et al., too, focus on situations in which the unwanted touching is related to other violations of the freedom of movement and elements of force, such as being locked up, restrained or violated while in a particularly vulnerable state (2014). Based on descriptions of unwanted touching, Stefansen et al. distinguish between three different forms of unwanted touching: sexual invasion, explorative touching and aggressive touching (2014).

Like Sørensen (2013), Stefansen et al. (2014) theorise from victims' experiences by drawing on the concept of a continuum of sexual violence. They both take as their starting point the misfit between victims' experiences and the available concepts. While Sørensen (2013) focusses on reintegrating sexual violence with other forms of severe IPV and the level of experience, Stefansen et al. (2014) focus on the distinctions between different forms of 'mild' sexual violations outside of couple relationships. By developing a typology of different forms of unwanted touching, Stefansen et al. (2014) contribute to recognising and naming such experiences. Introducing Dahl's (1994) concept of gender freedom as a normative standard against which to measure these experiences, the new typology becomes an important tool for recognising, naming and resisting unwanted touching, thereby clarifying and reducing the ambiguity of the victim position.

\section{The structural intersectional approach}

Andersson et al. (2016), a multidisciplinary research group, based on law, gender studies, ethnology and history, present in their paper a research project on Swedish discourses on rape since 1990. The project focusses on the production of hegemony and truth by an examination of three kinds of sources and the relations between them: (1) legal texts on rape (with a focus on discussions of force and consent) and the intersections of power and subordination in such texts; (2) rape narratives in the media and the consequences for political mobilisation of the separation of rape narratives into different types/genres, depending on the relation to the perpetrator or the context; and (3) biographical stories in the response to social media campaigns, with a focus on the role of personal experience in political mobilisation.

Andersson et al. (2016) draw on feminist critiques of 'linking rape to sexuality, which in turn is constructed as the basis for the inner (core) of human beings' (p. 88). Following Carine Mardorossian's work (2014), Andersson et al. (2016) draw on Susan Brownmiller's (1975) and Michel Foucault's work on the sexualisation of bodies in Western culture $(1979,1990,1992)$. Brownmiller problematised the concept of consent from a radical feminist perspective (1975, p. 384, cited in Andersson et al., 2016, p. 87), arguing that the idea of consent was based on a liberal view of women's bodies as autonomous and rape as a violation of 
individual integrity. This view is at odds with the radical feminist theoretical position that rape is a question of gender and power at the societal level.

Second-wave feminists framed rape as violence against women and introduced the concept of power at the system level (i.e. through patriarchy) into the public debate on rape. They also widened the understanding of what rape is and who can be raped. According to Brownmiller (1975), rape is a political act, the purpose of which is to frighten and degrade women as a group. Andersson et al. (2016) argue that the benefit of this perspective, which separated rape from sexuality, was to make the question of consent irrelevant; thus, issues of shame and guilt, and the related victim role, are also irrelevant. If we think of rape as being related to sex, then the victim is made complicit via the notion of consent, which then leads to personal shame and guilt. In contrast, Brownmiller (1975) argued that women were victims only of patriarchal power, thus offering a victim position linked to agency and resistance.

Andersson et al. (2016) also refer to the work of Ann Cahill (2001), who argues from a phenomenological feminist perspective that draws on feminist theorisations of the body as the basis of gender difference and the inscription of power. Following Mardorossian (2002, 2014), Andersson et al. (2016) also refer to Foucault's $(1979,1990,1992)$ work on the perpetual reproduction of the body as sexual (specifically heterosexual) and the reduction of human existence to the use of the body's reproductive organs. Foucault (1977) argued that resistance should be directed against the discursive power that describes sexuality as the core of being human; this discourse underpins the perception that rape is the worst that can happen to a woman, since it robs her of her worth as a human being.

With Mardorossian (2002, 2014), Andersson et al. (2016) want to return to the second-wave feminist view on rape victims as active subjects rather than what they see as the prevailing view: as objects to be acted on by victimologist help agencies. Emphasising structural-intersectional positions and the decoupling of rape from erotic sexuality, Andersson et al. (2016) contribute to the ongoing theoretical endeavours to synthesise radical feminist thinking, feminist theories of the body and poststructuralist thinking. Focussing on power relations and political mobilisation, they invoke the legacy of radical feminist theorisations in which sexual violence was viewed as an expression of gendered power relations.

\section{The dialectic critical-realist approach}

Gunnarsson (2018) explores the tensions between dominant popular understandings that discursively juxtapose sex and rape and the more continuum-like and ambiguous realm of experience in women's and non-binary people's narratives of sexual encounters in the 'grey zone' between sex and abuse. She then analyses narratives of men who do not want sex and male victims of sexual abuse, as a contrast to discourses that presume men always want sex and that ignore men's vulnerability and victimisation. Related to the lack of fit between discourse and experience, she argues that experiences and gendered subjectivities are shaped by discourses. 


\section{Margunn Bjørnholt}

Gunnarsson (2018) aims to reconcile discursive constructions of sexual violence and experiences of sexual violence by suggesting a dialectic approach inspired by critical realism (Bhaskar, 2008). Scholars of feminist theory have hotly debated the relationship between experience and discourse (Scott, 1992; Alcoff, 2000). And, in research on sexual violence and victimisation, poststructuralist scholars have argued that the concepts and discourses typically used to name sexual violence may perpetuate the problem they describe by locking women in a powerless position of rapability (Marcus, 2002). Others see this argument as a trivialisation of women's experiences and have argued that rape is not a discursive problem (Hawkesworth, 1989; Mardorossian, 2002). Gunnarsson (2018) carves a path through this polarisation between the realist and discursive approaches by exploring the dialectic between dominant discourses on sex and people's reported experiences in the grey zone between sex and sexual violence. Referring to the work of Linda Alcoff $(2000,2014)$ ), among others, Gunnarsson argues that experiences and discourses mutually influence each other (2018).

In her analysis of this grey area between sex and rape, Gunnarsson (2018), too, draws on a continuum perspective. She refers to Gavey $(1999,2005)$, who argues that it is difficult to draw a line between 'just sex' and sexual violence, and to scholars who have pointed to the similarities and overlap in the scripting of heterosexual romance/sexual pursuit and rape (Gilbert \& Webster, 1982, cited in Kelly, 1988a, p. 74; Gunnarsson, 2018, p. 7). This notion was most radically formulated by Catharine MacKinnon (1989), who questioned how to tell the difference between normal sex and violence in a culture and a sexual and gendered reality that eroticises male power and female submission. In a less reductionist form of this insight, Gunnarsson (2018) also refers to the observation that normative heterosexuality is infused with violent dynamics and can be thought of as a continuum in which typical male behaviours and 'aberrant' male behaviours shade into one another, as formulated in Kelly's continuum concept (1988a, p. 75). MacKinnon's (1989) and Kelly's (1987, 1988a, 1988b) ideas have been taken up and reworked in later explorations of the ambiguous grey area between the categories of sex and sexual violence (Gavey, 1999, 2005; cf. Powell, 2008; Cunniff Gilson, 2016).

With Gavey, Gunnarsson also argues that scholars who endorse a 'dimensional' view of sexual violence generally operate on two levels, which they normally do not explicitly distinguish: (1) sex and violence are often difficult to distinguish within the experience, and (2) the discursive scripting of heterosexual sex and sexual violence overlaps (Gavey, 1999, p. 60, cited in Gunnarsson, 2018, p. 7).

This tension between discourse and experience was what fuelled the \#prataomdet ('talkaboutit') campaign in Sweden. An important framing of the campaign was the need for a new language to map nuances in people's experiences of sex and violence. In her analysis of women's narratives from the campaign, Gunnarsson (2018) found that the grey area was in the difficulty in discerning the boundary between sex and violence. In analysing these narratives, Gunnarsson (2018) draws on feminist scholarship on rape and 'rape scripts', referring to Kathryn Ryan's work (2011): if rape is constructed as 
something monstrous and removed from everyday life, while in reality it shades into common sexual affairs, then this discourse makes it difficult to identify, both at an individual and societal level.

Gunnarsson (2018) finds that the rape script makes it difficult both to name experiences of sexual violence and to stop acts of sexual violence. In one \#prataomdet story, that lends her article its title, a woman woke up in pain, realising her boyfriend had done things to her that she had not consented to, but she had not intervened or tried to stop him. The woman asked in retrospect, 'What was I supposed to say? "Excuse me, but are you raping me now?" The rape script also makes it difficult to confront the perpetrator. In another \#prataomdet story, the victim ended up comforting the perpetrator: after confronting her boyfriend that he had raped her in her sleep, he started to cry and made her take it back, as he could not bear being a rapist, thus illustrating the risks involved in rendering one's partner a 'psychopathic monster'.

In analysing the male-authored narratives in the \#prataomdet campaign, Gunnarsson (2018) refers to the shared foundation of both sex and rape in the discourse on the 'male sex drive'. A man who does not want sex not only violates the social expectation of men always wanting sex but also violates his masculine identity that was formed by this discourse. Exploring the gap between his experience of not wanting sex while at the same time wanting or claiming to want it, Gunnarsson (2018) explores how discourses may simultaneously shape expectations and subjectivities and produce tensions at an individual level.

Like Andersson et al. (2016), Gunnarsson, too, can be seen as synthesising different strands and different generations of feminist theorisations of rape by exploring the gaps in accounts of grey-zone experiences between discourses and experiences (2018). In involving theorisations of grey zones that draw on feminist theorisations in which rape is viewed as being related to 'just sex' in the MacKinnon (1989) tradition, Gunnarsson (2018) explores the ambiguities of the victim position. Her contribution illustrates the need to empirically study and to critically discuss the discursive framings of experience as well as the role of discourses in shaping gendered subjectivities and interactions.

\section{The institutional approach}

In Stopping Rape (2015), Walby and co-authors - among them Sofia Strid, who is a Swedish scholar, which is why this general work on rape is included in the present volume on rape in the Nordic countries - argue that the theorisation and prevention of rape requires a broad, institutional approach and a theoretical model that will account for the complex, causal pathways to rape. Taking a holistic, complex-systems approach, the authors argue that the production and prevention of rape can be understood to occur at three levels of analysis: (1) societal-level systems (gender regimes and overall violence); (2) social institutions (planning/political, health, conflict/military, civil society, economics, and law and criminal justice); and (3) the level of individual victims and rapists. Looking not only at individuals but also at the effects of other institutions 
relevant to rape, the authors emphasise how both the understanding of causal pathways to rape and rape prevention may be affected by changes at all these levels; they also discuss how changes at one level may affect the other levels via feedback systems.

Support services for victims are one example: better-supported victims (i.e. the individual level) may be empowered to endure the criminal justice process, thus leading to more convictions (i.e. the institutional level). Further, empowered victims will be capable of speaking out and educating the public and politicians on the reality of rape, which will challenge rape myths and contribute to the prevention of rape. In this conceptualisation, the mutual relations between experience and discourse, theorised in several of the previous contributions, are thought of as part of possible feedback systems in a complex system. Further, the general level of gender inequality/equality policies and the social systems of violence in particular societies shape the institutions that are relevant to rape.

The authors develop their model by detailing six institutional fields: (1) strategy, planning and coordination; (2) victim and healthcare systems; (3) law and criminal justice systems; (4) conflict zones (specifically rape in such zones); (5) culture, media and education; and (6) economics. They present their research findings as well as selected successful interventions within each field. This broad scope is enabled by the book's co-authorship by a large, interdisciplinary and international team of scholars who provide a broad overview, combined with deep insights into the particular issues they cover. For instance, the authors argue that economic gender inequality is related to rape; indeed, previous studies have found that unemployed women are more often exposed to rape (Walby \& Allen, 2004; Kelly, Horvarth, Uzelac, \& Lovett, 2007). Riger, Staggs, and Schewe (2004) found an inverse relationship between work stability and rape, which might be an important finding in the context of the increasing precariousness of the labour market. Research by one of the Stopping Rape co-authors, Bina Agarwal, shows how in India, purported employment may take the form of unpaid work in the family business, which often provides neither a decent income nor autonomy (Agarwal \& Panda, 2007). Rather than such positions providing employment as such, Agarwal and Panda found that having access to property and other tangible economic means had a protective effect (2007). This scenario illustrates that strategies of women's economic empowerment as part of preventing rape must be well researched and specific.

The holistic-systemic approach, which emphasises the interplay between different systems at different levels, calls for research at different levels as well as at an overall systems level. Walby et al. (2015) argue that understanding the causal pathways to rape requires theoretically and empirically determining the interactions between different institutional fields and the working of feedback systems. Some of the other approaches' theoretical concerns are also present in Walby et al.'s (2015) contribution, such as the importance of discourses and that victims speak up. In their approach, however, the focus is not predominantly on the internal relationship between discourse and experience but on how these factors interact with other elements in the social system. Further, the use 
of this approach also implies an ambition and a need to theorise and understand the operation of combined systems at a macro level. By introducing the concept of violence regimes and linking them to gendered welfare-state regimes, Strid (the Swedish co-author mentioned earlier) has proceeded in this direction in a new study on 'Gendered violence regimes' (Delaunay \& Strid, 2018).

\section{Theoretical diversity and innovation}

This review, although far from exhaustive, has revealed some of the theoretical diversity and innovation found in making sense of sexual violence among Scandinavian scholars and mirrors the growth in-depth and sophistication notable in theoretical approaches in the field internationally (Brown \& Walklate, 2011). The contributions also demonstrate the continued relevance and theoretical potential of renewed and continued involvement with different strands of second-wave feminist theorisations of sexual violence.

The four approaches presented in this chapter explicitly draw on or involve earlier feminist work while also reflecting and reproducing some of the controversies between different strands of early feminist theorisations on core issues such as the relation between sex and violence. Andersson et al. (2016), for example, drawing on the work of Brownmiller (1975) and Foucault (1977, 1979, 1990, 1992), position themselves against linking sex and rape, while Gunnarsson (2018) explores the grey zone between sex and rape and takes as her starting point that sex and rape can be understood as a continuum - a position most radically formulated by MacKinnon (1989) and reworked and nuanced by others such as Gavey (2005). The continuum concept (Kelly, 1987, 1988a, 1988b) features prominently in three of the contributions. The widespread and different ways in which the authors use the continuum concept illustrate the idea's continued relevance and analytical usefulness, as well as how the concept can be employed in various - and not necessarily compatible - ways.

\section{Different uses of the continuum concept}

Sørensen (2013) draws on the continuum concept to explore the relations between sexual violence and other forms of violence (such as domestic violence) from intimate partners. He argues that sexual violence may well be part of a more general picture of violence and that victims of domestic violence (which often includes sexual violence) do not necessarily distinguish between different forms of violence at the experiential level. In their use of the concept, Stefansen et al. (2014) hope to coin new concepts for sexual experiences in the grey zone between sex and violence. They also draw on the concept of a continuum at an experiential level by linking acts of sexual violence to other acts of force and the violation of freedom of movement; in addition, they refer to the wider cultural level and link minor sexual offences by acquaintances to sexualised micro-aggression in the public sphere, both of which limit girls' and women's gender freedom. 


\section{Margunn Bjørnholt}

Gunnarsson (2018), who also explores grey-zone experiences, focusses on the continuum between sex and rape. Walby et al. develop a wider institutional approach that transcends the continuum approach, which they refer to only briefly as a way of capturing 'the way in which small events are connected to create a context that is more threatening than the sum of its parts' $(2015, \mathrm{p} .12)$.

\section{Conceptualisations of the victim}

One common denominator among these studies is a general concern for working out concepts of victimisation that will leave room for agency, hence challenging notions of victimisation that imply passivity. Andersson et al. (2016) explicitly draw on second-wave feminist theorisations, in particular Brownmiller's (1975), to revitalise the link between victimhood and agency. So does Sørensen (2013), who draws on feminist conceptualisations (Merry, 2003) in which the victim is viewed as a violated legal subject - a position from which to act and a prerequisite for agency (Kelly, Burton, \& Regan, 1996), in contrast to being a 'broken subject' - as well as drawing on Riches's (1986) tripartite model of victimhood. In this model, which involves the victim, the perpetrator, and one or more witnesses, the broader culture and general attitudes to rape are included in the definition of the witness and the role witnesses play in the model.

Walby et al. (2015) explicitly limit their investigation to rape; in their contribution, victims of rape are victims of criminal acts. In their discussion of feedback systems that might influence understandings and social and legal responses to rape, Walby et al. also use as an example the possible effects of changes in the legal and social responses to rape for victims who speak up.

This strong emphasis on the victim's agency may be seen as part of an effort to repoliticise the field and to mobilise rape victims' voices in the political struggle against rape. This focus on agency and voice may be problematic, however, in that it may produce new normative expectations as to how victims should act. For instance, the imperative to be strong and agentic, to speak out and to report, may be felt as a moral norm but may not be in an individual victim's interest. In a recent master thesis, Marie Louise Hansen (2018) highlights how rape victims negotiate these norms in order to avoid the personal and social costs of reporting.

Gunnarsson (2018) discusses the ambiguity of the victim position and how hegemonic discourses may make it difficult to identify sexual violence or to harbour non-typical victims' experiences and vulnerabilities. Sørensen (2013) and Stefansen et al. (2014) also highlight the lack of fit between the available concepts and the experiences of sexual violence.

\section{Gender theory}

All the contributions analysed so far have explicitly drawn on and engaged with theories of gender and sexual violence, and some have also drawn on more general gender theories. Sørensen (2013) and Stefansen et al. (2014), who use the continuum approach, analyse empirical material and contribute to new 
conceptualisations and theorisations of sexual abuse while also discussing such abuse's link to gender hierarchies (Sørensen, 2013) and gender cultures that limit women's and girls' gender freedom (Stefansen et al., 2014). Sørensen (2013) mainly refers to theories of gender violence and argues for including sexual violence in general studies of domestic violence/IPV.

Andersson et al. (2016) also employ more general feminist and poststructural theories, including feminist theories of the body, and focus on gendered power relations and political mobilisation related to gender and violence. Gunnarsson (2018) combines second-wave feminist theorisations of sexual violence and poststructural approaches with critical realism, with the aim of theorising the gap between discourses and experiences. Walby et al. (2015) cite gender theories and policies at the international and national levels to develop a holistic model of the social production and prevention of rape.

\section{Concluding remarks}

The aim of this review has been to map various theorisations of sexual violence that are potentially relevant for understanding sexual violence in intimate relations as a gendered phenomenon. The contributions presented in this chapter differ both in terms of which acts of sexual violence they address and in which kinds of relationships and perpetrators they include and exclude. Only one contribution (Sørensen, 2013) addresses sexual violence from partners alone (as part of domestic violence); the other contributions address sexual violence per se and in different relations.

A comprehensive approach to sexual violence as a gendered phenomenon needs to draw on and synthesise a variety of perspectives in order to explain the co-production of gender and sexual violence that results in this gendered pattern of victimisation and perpetration. Such an approach also needs to explain how this gendered phenomenon is linked to broader processes in contemporary societies that produce and facilitate sexual violence - in ways that will not exclude the experiences of victims and perpetrators who do not fit with the general gendered pattern of sexual violence. This goal demands a multidimensional and multilevel approach - in line with what Walby et al. (2015) propose - that will take into consideration different institutional levels, from particular institutions to national regimes, of gender and violence. The individual and interactional levels are still important, however, and we need to be able to recognise and name grey-zone experiences. With their typology of unwanted touching, Stefansen et al. (2014) have provided tools for recognising, naming, and potentially resisting such events. In line with Gunnarsson's (2018) dialectic critical-realist approach, I would add the need to further explore gendered subjectivities and discourses (and the tensions between them) as well as ontological sex differences. Finally, and in line with Sørensen (2013), we must explore how sexual violence from intimate partners is part of the broader picture of IPV and discuss the gains and potential problems of singling out sexual violence as a particular field of study, separate from IPV studies. 


\section{Margunn Bjørnholt}

The recent rapprochement of poststructuralist and radical feminist theories (which is also visible in the Scandinavian context) may be seen as part of an ongoing process of theorising from the experiences of new generations who are trying to understand sexual violence in the context of the uneven process of changing gender structures, gender discourses, gender relations, and gendered subjectivities. The continued relevance and engagement with radical feminist theorising in recent theorisations of sexual violence may be thought of as arising from the need to theorise gender-power relations. We must study the experiential continuum of sexual violence in different contexts and relationships in order to understand, recognise and name such experiences and to construct categories that will represent victims' lived experiences. Theorisations of rape, sexual harassment and grey zones in other-than-intimate relationships may also be helpful in making sense of sexual violence in intimate relations (see Bjørnholt \& Helseth, 2019). Nevertheless, we must further explore sexual violence in intimate relationships, specifically within the relational dynamics of couple relationships.

\section{Note}

1 The choice to select only publications from the Scandinavian countries is a pragmatic one. As a Norwegian, the author also reads languages Danish and Swedish, but not the languages of the other Nordic countries.

\section{References}

Agarwal, B., \& Panda, P. (2007). Toward freedom from domestic violence: The neglected obvious. Journal of Human Development, 8(3), 359-388.

Alcoff, L. M. (2000). Phenomenology, post-structuralism, and feminist theory on the concept of experience. In L. Fisher \& L. Embree (eds.), Feminist phenomenology (pp. 39-56). Dordrecht, the Netherlands: Springer.

Alcoff, L. M. (2014). Sexual violations and the question of experience. New Literary History, 45(3), 445-462.

Andersson, U., Edgren, M., Karlsson, L., \& Nilsson, G. (2016). Våldtäkt i Sverige 1990-2013: Ett historiskt och intersektionellt perspektiv på berättelser om våldtäkt inom olika genrer [Rape in Sweden 1990-2013: A historical and intersectional perspective on narratives of rape in different genres]. Gränsløs: Tidskrift för studier av Öresundsregionens historia, kultur och samhällsliv [Limitless: Journal of Studies of the History, Culture and Religion of the Öresund Region], 6, 82-92.

Bhaskar, R. (2008). Dialectic: The pulse of freedom. London: Routledge.

Bjørnholt, M., \& Helseth, H. (2019). 'Jeg ville jo si nei' - Seksuell vold i parforhold ['I would have said no' - Sexual violence in intimate relations]. In K. Skjørten, E. Bakketeig, M. Bjørnholt, \& S. Mossige (eds.), Vold i noere relasjoner [Violence in intimate relations]. Working title. Oslo: Universitetsforlaget, 86-103.

Brown, J. M., \& Walklate, S. L. (eds.). (2011). Handbook on sexual violence. London \& New York: Routledge.

Brownmiller, S. (1975). Against our will: Rape, women, and men. New York: Simon \& Schuster.

Cahill, A. J. (2001). Rethinking rape. Ithaca, NY: Cornell University Press. 
Cunniff Gilson, E. (2016). Vulnerability and victimization: Rethinking key concepts in feminist discourses on sexual violence. Signs: Journal of Women in Culture and Society, 42(1), 71-98.

Dahl, T. S. (1994). Pene piker haiker ikke: Artikler om kvinnerett, strafferett og velferdsstat [Nice girls don't hitchhike: Articles on women's law, criminal law, and the welfare state]. Oslo: Universitetsforlaget, and Copenhagen: Akademisk Forlag.

Delaunay, M., \& Strid, S. (2018). Gendered violence regimes: Context, policy and practice in intimate partner violence in France and Sweden. Presentation at the IXI ISA World Congress of Sociology, July 15-21, Toronto.

Doucet, A. (2015). Parental responsibilities: Dilemmas of measurement and gender equality. Journal of Marriage and Family, 77(1), 224-242. doi:10.1111/jomf.12148

Foucault, M. (1977). La folie encerclée. Paris: Change Collective.

Foucault, M. (1979 [1976]). The history of sexuality volume 1: An introduction. London: Allen Lane.

Foucault, M. (1990 [1984]). The history of sexuality volume 3: The care of the self. London: Penguin Books.

Foucault, M. (1992 [1984]). The history of sexuality volume 2: The use of pleasure. London: Penguin Books.

Gavey, N. (1999). 'I wasn't raped, but ...': Revisiting definitional problems in sexual victimization. In S. Lamb (ed.), New versions of victims: Feminists struggle with the concept (pp. 57-81). New York and London: New York University Press.

Gavey, N. (2005). Just sex: The cultural scaffolding of rape. New York: Routledge.

Gilbert, L., \& Webster, P. (1982). Bound by love: The sweet trap of daughterhood. Boston: Beacon Press.

Gunnarsson, L. (2018). 'Excuse me, but are you raping me now?' Discourse and experience in (the grey areas of) sexual violence. NORA: Nordic Journal of Feminist and Gender Research, 26(1), 4-18.

Hansen, M. L. J. (2018). Vilje og motvilje: Fortellinger bak ikke-anmeldte voldtekter [Will and resistance: Stories behind non-reported rapes]. Master thesis. University of Oslo.

Hawkesworth, M. E. (1989). Knowers, knowing, known: Feminist theory and claims of truth. Signs: Journal of Women in Culture and Society, 14(3), 533-557.

Hemmings, C. (2005). Telling feminist stories. Feminist Theory, 6(2), 115-139.

Hemmings, C. (2011). Why stories matter: The political grammar of feminist theory. Durham, NC: Duke University Press.

Hester, M., \& Donovan, C. (2009). Researching domestic violence in same-sex relationships: A feminist epistemological approach to survey development. Journal of Lesbian Studies, 13(2), 161-173.

Kelly, L. (1987). The continuum of sexual violence. In J. Hanmer \& M. Maynard (eds.), Women, violence and social control (pp. 46-60). London: Palgrave Macmillan.

Kelly, L. (1988a). Surviving sexual violence. Cambridge, UK: Polity Press.

Kelly, L. (1988b). How women define their experiences of violence. In K. Yllo \& M. Bograd (eds.), Feminist perspectives on wife abuse (pp. 114-132). Thousand Oaks, CA: Sage.

Kelly, L., Burton, S., \& Regan, L. (1996). Beyond victim or survivor: Sexual violence, identity and feminist theory and practice. In L. Adkins \& V. Merchant (eds.), Sexualizing the social (pp. 77-101). London: Palgrave Macmillan.

Kelly, L., Horvarth, M., Uzelac, G., \& Lovett, J. (2007). Rape in the 21st century: Old behaviours, new contexts and emerging patterns. Swindon, UK: Final Report to the Economic and Social Research Council (ESRC). 


\section{Margunn Bjørnholt}

MacKinnon, C. A. (1989). Toward a feminist theory of the state. Cambridge, MA: Harvard University Press.

Marcus, S. (2002). Fighting bodies, fighting words: A theory and politics of rape prevention. In J. Butler \& J. W. Scott (eds.), Feminists theorise the political (pp. 403-421). New York and Abingdon, UK: Routledge.

Mardorossian, C. M. (2002). Toward a new feminist theory of rape. Signs: Journal of Women in Culture and Society, 27(3), 743-775.

Mardorossian, C. M. (2014). Framing the rape victim: Gender and agency reconsidered. New Brunswick, NJ and London: Rutgers University Press.

Merry, S. E. (2003). Rights talk and the experience of law: Implementing women's human rights to protection from violence. Human Rights Quarterly, 25(2), 343-381.

Merry, S. E. (2009). Human rights and gender violence: Translating international law into local justice. Chicago and London: University of Chicago Press.

Powell, A. (2008). Amor fati? Gender habitus and young people's negotiation of (hetero) sexual consent. Journal of Sociology, 44(2), 167-184.

Riches, D. (1986). The phenomenon of violence. In D. Riches (ed.), The anthropology of violence. Oxford, UK: Basil Blackwell, 1-28.

Riger, S., Staggs, S. L., \& Schewe, P. (2004). Intimate partner violence as an obstacle to employment among mothers affected by welfare reform. Journal of Social Issues, 60(4), 801-818.

Ryan, K. M. (2011). The relationship between rape myths and sexual scripts: The social construction of rape. Sex Roles, 65(11-12), 774-782.

Scott, J. W. (1992). Experience. In J. Butler \& J. W. Scott (eds.), Feminists theorise the political (pp. 40-58). New York and Abingdon, UK: Routledge.

Sheffield, C. J. (1989). The invisible intruder: Women's experiences of obscene phone calls. Gender \& Society, 3(4), 483-488.

Smart, C. (1995). Law, crime and sexuality: Essays in feminism. London, Thousand Oaks, CA, and New Delhi: Sage.

Somers, M. (1995). What's political or cultural about political culture and the public sphere? Toward an historical sociology of concept formation. Sociological Theory, 13 (2), 113-144. doi:10.2307/202157

Sørensen, B. W. (2013). Voldens kontinuum og kvinders voldserfaringer [The continuum of violence and women's experiences of violence]. Sosiologi i dag [Sociology Today], 43(4), 69-93.

Steen, A.-L. (2003). Mäns våld mot kvinnor - Ett diskursivt slagfält: Reflektioner kring kunskapsläget [Men's violence against women - A discursive battlefield: Reflections on knowledge status]. Göteborg, Sweden: Göteborgs universitet sociologiska institutionen.

Stefansen, K., Smette, I., \& Bossy, D. (2014). Angrep mot kjønnsfriheten: Unge jenters erfaringer med uønsket beføling [Attack on gender liberty: Young girls' experiences with unwanted touching]. Tidsskrift for kjønnsforskning [Journal of Gender Studies], 38(1), 3-19.

Walby, S., \& Allen, J. (2004). Domestic violence, sexual assault and stalking: Findings from the British Crime Survey. London: Home Office.

Walby, S., Olive, P., Towers, J., Francis, B., Strid, S., Krizsan, A., ... Armstrong, J. (2015). Stopping rape: Towards a comprehensive policy. Bristol: Policy Press.

Walby, S., \& Towers, J. (2017). Measuring violence to end violence: Mainstreaming gender. Journal of Gender-Based Violence, 1(1), 11-31. 